\title{
PENGARUH KOMPENSASI, PERSEPSI DUKUNGAN ORGANISASI DAN PENGEMBANGAN KARIR TERHADAP RETENSI KARYAWAN
}

\author{
I Gde Manik Aditya Budi Suta ${ }^{1}$ \\ I Komang Ardana ${ }^{2}$
}

\author{
${ }^{1,2}$ Fakultas Ekonomi dan Bisnis Universitas Udayana (Unud), Bali, Indonesia \\ E-mail: manikadityabudhi@gmail.com
}

\begin{abstract}
ABSTRAK
Penelitian ini dilakukan untuk mengetahui pengaruh kompensasi, persepsi dukungan organisasi dan pengembangan karir terhadap retensi karyawan PT. BPR Gianyar Partasedana. Populasi yang digunakan adalah seluruh karyawan tetap PT. BPR Gianyar Partasedana yang berjumlah 53 orang karyawan. Metode penentuan sampel yaitu nonprobability sampling dengan teknik sampling jenuh yang melibatkan semua populasi dijadikan sampel. Pengumpulan data dilakukan dengan cara kuesioner, wawancara, dan observasi. Teknik analisis data yang digunakan adalah regresi linear berganda. Hasil penelitian ini menunjukan bahwa kompensasi berpengaruh positif dan signifikan terhadap retensi karyawan, hal ini menunjukkan semakin tinggi kompensasi yang diberikan maka akan meningkatkan retensi. Untuk variabel persepsi dukungan organisasi berpengaruh positif dan signifikan terhadap retensi karyawan, hal ini menunjukkan semakin besar dukungan organisasi maka akan meningkatkan retensi. Selanjutnya untuk variabel pengembangan karir berpengaruh positif dan signifikan terhadap retensi karyawan, hal ini menunjukkan semakin besar pengembangan karir yang diberikan maka semakin tinggi tingkat retensi karyawan.
\end{abstract}

Kata kunci: kompensasi, persepsi dukungan organisasi, pengembangan karir, retensi karyawan

\begin{abstract}
This study was conducted to determine the effect of compensation, perceptions of organizational support and career development on employee retention of PT. Gianyar Partasedana BPR. The population used is all permanent employees of PT. Gianyar Partasedana BPR, amounting to 53 employees. The sample determination method is nonprbability sampling with saturated sampling technique that involves all populations being sampled. Data collection was carried out by means of questionnaires, interviews, and observations. The data analysis technique used is multiple linear regression. The results of this study indicate that compensation has a positive and significant effect on employee retention, this shows that the higher the compensation given, it will increase retention. For organizational support perception variables have a positive and significant effect on employee retention, this shows that the greater the support of the organization, it will increase retention. Furthermore, for career development variables have a positive and significant influence on employee retention, this shows that the greater the career development given, the higher the employee retention rate.
\end{abstract}

Keywords: compensation, perception of organizational support, career development, employee retention 
I Gde Manik Aditya Budi Suta, Pengaruh Kompensasi...

\section{PENDAHULUAN}

Suatu organisasi harus cepat merespon segala bentuk perkembangan yang terjadi, terutama pada persaingan bisnis yang semakin ketat agar organisasi mampu bertahan. Guna mewujudkan hal tersebut diperlukannya Sumber Daya Manusia (SDM) yang berkualitas. SDM yang berkualitas adalah SDM yang memiliki keterampilan, kemampuan, pengetahuan, dan sikap yang baik dalam bekerja.Menurut Ardana dkk. (2012:3), SDM adalah harta atau aset paling berharga dan paling penting dimiliki oleh suatu organisasi/perusahaan karena keberhasilan organisasi sangat ditentukan oleh unsur manusia yang berperan sebagai perencana, pelaksana sekaligus pengendali terwujudnya tujuan organisasi.

Dalam era globalisasi, potensi-potensi yang dimiliki SDM dituntut agar dikembangkan.Kegagalan dalam mengelola SDM dapat berdampak pada sasaran yang sudah direncanakan didalam organisasi baik profit, kinerja maupun kelangsungan hidup organisasi.Maka dari itu, SDM yang diperlukan, yaitu SDM yang adaptif dan responsif terhadap perubahan-perubahan yang terjadi.Kesuksesan organisasi atau perusahaan tergantung pada efisiensi, ketekunan,dan kinerja karyawan. Kinerja karyawan memiliki peranan penting bagi perusahaan, apabila kinerja yang ditampilkan karyawan rendah maka akan mengakibatkan perusahaan dalam mencapai tujuan menjadi terhambat (Ariana dan Riana, 2013). Diah (2014), menyatakan seiring dengan persaingan eksternal yang semakin tinggi setiap perusahaan perlu mempersiapkan strategi dari sisi internal seperti mengembangkan dan mempertahankan karyawan yang memiliki kinerja terbaik agar perusahaan tetap memiliki suatu value added(nilai tambah) 
dan mampu bertahan di tengah persaingan yang tajam. Dessler (2013:85),lebih jauh menyatakan bahwa berkembangnya suatu perusahaan tidak lepas dari dukungan pihak internal perusahaan salah satunya adalah berasal dari tata kelola SDM yang ada dalam suatu perusahaan.

Organisasi sangat memperhatikan betapa pentingnya mempertahankan karyawan karena kunci keberhasilan suatu organisasi tergantung pada retensi karyawan(Das dan Baruah, 2013). Hasibuan (2014:120) menyatakan retensi karyawan erat kaitannya dengan program untuk pemeliharaan (maintenance), pemeliharaan tersebut dilakukan dengan sasaran kondisi fisik, mental, dan sikap loyal karyawan terhadap pekerjaannya. Program maintenance dapat berjalan dengan baik apabila dilakukan bersamaan dengan program pemberian kesejahteraan yang dibutuhkan oleh karyawan serta berpegang pada konsistensi internal dan eksternal dalam perusahaan dengan harapan meningkatkan retensi karyawan pada suatu perusahaan.

Retensi karyawan sangat terkait dengan perputaran karyawan atau keluar masuknya karyawan, di mana sifat hubungannya berbanding terbalik. Hal tersebutdimaksudkan bahwa jika tingkat retensi karyawan tinggi, maka berarti tingkatperputaran karyawan dalam suatu perusahaan rendah dan jika tingkat retensikaryawan rendah, maka berarti tingkat perputaran dalam suatu perusahaan tinggi(Swambawa Putra, 2016). Jika retensi karyawan dapat dijalankan dengan baik oleh perusahaan, maka pekerjaan yang dilakukan karyawan akan maksimal dan tujuan dari perusahaan dapat dicapai. Retensi karyawan membantu mengurangi pemborosan dalam hal waktu, tenaga dan uang yangdihabiskan dalam 
I Gde Manik Aditya Budi Suta, Pengaruh Kompensasi...

mempekerjakan dan melatih karyawan baru. Mencegah keluarnya karyawan yang memiliki keahlian dari organisasi merupakan tujuan utama dari retensi karyawan.

Gunawan (2011), menyatakan tingginya retensi karyawan maka akan menurunkan turnover karena memelihara retensi karyawan akan meningkatkan efektivitas dan kinerja perusahaan. Panggabean (2014),menyatakan bahwa tingginya retensi karyawan akan mempengaruhi kinerja organisasi dalam mencapai suatu tujuan dan misi organisasi. Oladopo (2014), mengatakan bahwa jika karyawan tidak dapat menggunakan potensinya dengan penuh dan juga tidak dihargai atau didengar di dalam tempat mereka bekerja, maka mereka akan keluar karena stres dan frustrasi. Tindakan dari karyawan tersebut yang dapat mengakibatkan kerugian bagi perusahaan yaitu memiliki keinginan untuk berhenti yang berujung pada keputusan untuk keluar (turnover intention). Oleh karena itu, perusahaan dituntut meningkatkan retensi dari karyawan agar kinerja dan produktivitas perusahaan tetap terjaga.

Kompensasi memiliki efek yang tinggi terhadap retensi karyawan karena salah satu tujuan utama kompensasi adalah mempertahankan karyawan terutama karyawan yang berkualitas baik (Vicky, 2012). Ardana dkk. (2012:153), menyatakan segala sesuatu yang diterima oleh karyawan sebagai balas jasa atas kontribusinya kepada perusahan atau organisasi dapat dikatakan sebagai kompensasi. Bila kompensasi tersebut dikelola dengan baik, maka akan dapat membantu perusahaan dalam mencapai tujuan, bila tidak dikelola dengan baik, maka akan mengganggu jalannya usaha.Kompensasi merupakan keseluruhan balas jasa yang diterima oleh karyawan sebagai balas jasa dari pelaksanaan 
pekerjaan di organisasi dalam bentuk uang atau lainnya yang dapat berupa gaji, upah, bonus, insentif, dan tunjangan, seperti tunjangan kesehatan, tunjangan hari raya, uang makan, cuti dan lain-lain (Rachmawati,2011:146).Hasibuan (2014:118), menyatakan bahwa kompensasi adalah suatu yang diberikan kepada karyawan sebagai timbal balik kontribusi yang mereka berikan yang berupa uang, barang atau imbalan lainnya. Lubis (2015), menyatakan bahwa kompensasi merupakan hal yang penting bagi karyawan karena upah merupakan suatu bentuk nilai yang diterima oleh karyawan atas kinerjanya yang diberikan untuk perusahaan.

Selain kompensasi, Swambawa Putra (2016), dalam penelitiannya menyatakan bahwa persepsi dukungan organisasi juga berpengaruh positif terhadap retensi karyawan. Persepsi dukungan organisasi merupakan sebuah persepsi dari karyawan terhadap suatu organisasi apakah organisasi peduli dan menghargai kesejahteraan karyawan atau tidak (Paille dan Bourdeau, 2010). Dukungan dari perusahaan akan mempengaruhi psikologis karyawan dalam bekerja, dengan kondisi psikologi yang positif karyawan akan mampu memberikan kemampuan terbaik yang bisa mereka lakukan kepada perusahaan (Mustika dan Rahardjo, 2017). Cahyana (2012), menyatakan bahwa apabila perusahaan memperhatikan karyawan maka upaya untuk mempertahankan dan meningkatkan retensi karyawan menjadi lebih mudah. Tingginya persepsi dukungan organisasi di dalam perusahaan yang mengarah kepada tingginya kepuasan kerja dan menurunkan tingkat turnover (Robbins dan Coulter, 2014:143). Menurut Benlioglu (2014), menyatakan beberapa alasan persepsi 
I Gde Manik Aditya Budi Suta, Pengaruh Kompensasi...

dukungan organisasi dibuatyaitu kondisi pekerjaan dan beberapa praktek sumber daya manusia memberikan penciptaan sikap positif karyawan. Perlakuan yang adil, dukungan pengawasan dan penghargaan serta kondisi kerja yang menguntungkan menunjukkan hubungan yang kuat dengan dukungan organisasi yang dirasakan.

Selain kompensasi dan persepsi dukungan organisasi, menurut Mathis dan Jackson (2011:128), bahwa retensi karyawan juga dipengaruhi oleh pengembangan karir secara signifikan. Karir merupakan jabatan atau status seseorang ketika bekerja selama hidupnya (Wahyuni dkk., 2014).Pengembangan karir memberikan kesempatan untuk pelatihan, promosi jabatan, dan pengembangan keterampilan guna meningkatkan kerja karyawan dalam suatu organisasi (Meyer \& Smith, 2000). Pengembangan karir adalah proses pengidentifikasi kemampuan karir karyawan dan melalui penerapan model yang tepat untuk mendapatkannya (Haryani,2013). Kwenin (2013), menyatakan bahwa organisasi yang memberikan pelatihan, fasilitas pendidikan kepada karyawan, maka karyawan tersebut lebih berkomitmen dan setia kepada organisasi dan karyawan yang diberikan pendidikan serta pelatihan akan mampu dalam meningkatkan produksi pada perusahaan.

PT. BPR Gianyar Partasedana adalah salah satu BPR yang ada di Gianyar sebagai perusahaan yang bergerak di bidang jasa keuangan. PT. BPR Gianyar Partasedana juga tidak lepas dari persaingan yang sangat ketat. Untuk dapat bertahan, dibutuhkan upaya maksimal dari pemilik dan manajemen BPR. Salah satu upaya untuk bertahan ditengah persaingan yang ketat adalah melalui 
dukungan kepada karyawan yang tetap loyal terhadap perusahaan. Pertanyaannya adalah bagaimana dapat mempertahakan karyawan yang sudah berpengalaman dan berdedikasi tinggi terhadap perusahaan.

PT. BPR Gianyar Partasedana sadar bahwa betapa pentingnya untuk mengembangkan kebijakan mempertahakan karyawan didalam sengitnya persaingan antar BPR pada khususnya dan didalam dunia jasa keuangan pada umumnya. Dari hasil wawancara yang dilakukan dengan pihak Kepala Bidang Operasional PT. BPR Gianyar Partasedana didapat bahwa salah satu masalah yang terjadi pada perusahaan yaitu adanya turnover. Banyak karyawan yang sering berfikir untuk keluar dari perusahaan, berfikir untuk meninggalkan pekerjaan, tidak mempunyai masa depan atau target yang pasti mengenai pekerjannya di perusahaan, hal ini mengindikasikan adanya tingkat turnover yang tinggi diperusahaan. Turnover yang tinggi akan mengakibatkan adanya biaya yang dikeluarkan perusahaan meliputi biaya rekrutmen, biaya seleksi, dan biaya pelatihan kepada karyawan baru, maka menarik untuk diteliti bagaimana cara untuk mempertahankan karyawan atau retensi karyawan di PT. BPR Gianyar Partasedana.

PT. BPR Gianyar Partasedana memiliki karyawan sebanyak 55 orang dan selama 1 Tahun terakhir mengalami turnover. Hal ini dapat dilihat pada Tabel 1. 
Tabel 1.

Data Turnover Karyawan Tetap pada PT. BPR Gianyar Partasedana Bulan Januari-Desember Tahun 2017

\begin{tabular}{cccc}
\hline Bulan & $\begin{array}{c}\text { Karyawan Masuk } \\
\text { (orang) }\end{array}$ & $\begin{array}{c}\text { Karyawan Keluar } \\
\text { (orang) }\end{array}$ & $\begin{array}{c}\text { Jumlah Karyawan } \\
\text { (orang) }\end{array}$ \\
\hline Januari & 1 & 1 & 55 \\
Februari & 1 & 2 & 54 \\
Maret & - & 1 & 53 \\
April & 1 & 1 & 53 \\
Mei & - & 2 & 51 \\
Juni & 1 & 1 & 51 \\
Juli & 1 & - & 52 \\
Agustus & 2 & 1 & 53 \\
September & 1 & - & 54 \\
Oktober & - & 3 & 51 \\
November & 1 & - & 52 \\
Desember & 1 & - & 53 \\
Jumlah & $\mathbf{1 0}$ & $\mathbf{1 2}$ & $\mathbf{5 3}$
\end{tabular}

Sumber: PT. BPR Gianyar Partasedana, 2017

Tabel 1 menunjukkan bahwa sejak bulan Januari sampai dengan bulan Desember Tahun 2017, terdapat turnover karyawan PT. BPR Gianyar Partasedana. Selama 1 Tahun terakhir, turnover tertinggi terjadi pada bulan Oktober, dimana tiga orang karyawan keluar dari perusahaan. Hasil wawancara dengan pihak Kepala Bidang Operasional PT. BPR Gianyar Partasedana, karyawan yang meninggalkan perusahaan yaitu pada departemen marketing dikarenakan Bank memberikan target kepada bagian marketing dan harus terpenuhi dalam waktu yang sudah ditentukan. Jika target tidak terpenuhi karyawan merasa tidak nyaman dalam melakukan pekerjaannya karena target yang diberikan tidak tercapai dan memutuskan untuk keluar dari perusahaan.Ratarata karyawan yang meninggalkan perusahaan karena gaji yang diterima tidak sesuai dengan beban kerja, kurangnya dukungan dari organisasi dan pekerjaan yang didapat tidak sesuai dengan kemampuan yang dimiliki. Penting bagi 
perusahaan untuk menerapkan sistem kompensasi, dukungan organisasi dan pengembangan karir dalam upaya mempertahankan karyawan yang berkualitas.

Ragupathi (2013), retensi karyawan mengacu pada teknik yang digunakan oleh manajemen untuk membantu karyawan tetap dengan organisasi untuk jangka waktu yang lama. Karthi (2012), berpendapat bahwa retensi karyawan adalah proses dimana karyawan didorong untuk tetap dengan organisasi untuk periode maksimum waktu atau sampai selesainya proyek. Dimana retensi karyawan juga merupakan keinginan karyawan untuk bertahan pada perusahaan dalam jangka waktu yang lama. Karyawan harus diperhatikan dan dipelihara dengan sungguhsungguh oleh manajer, jika tidak maka semangat kerja, loyalitas, sikap dan disiplin karyawan akan menurun. Namun, tidak semua karyawan akan keluar dari perusahaan, setidaknya masih banyak karyawan yang tetap bertahan bekerja pada perusahaan (retention).

Retensi karyawan didefinisikan oleh Mathis dan Jackson (2011:126), sebagai suatu bentuk upaya untuk mempertahankan karyawan, dimana hal tersebut telah menjadi persoalan utama dalam banyak organisasi karena beberapa alasan. Istilah retensi terkait dengan istilah perputaran karyawan yang berarti proses karyawan meninggalkan organisasi dan harus digantikan.Hafanti (2015),menyatakan bahwa retensi karyawan adalah kemampuan perusahaan untuk mempertahankan pekerja-pekerja terbaik untuk terus berada dalam organisasi. Perusahaan yang telah melakukan investasi dalam SDM akan sia-sia, apabila tidak dapat mempertahankan karyawannya untuk terus berada dalam perusahaan (Sari, 2014). Ketidakmampuan untuk mempertahankan karyawan menyebabkan 
I Gde Manik Aditya Budi Suta, Pengaruh Kompensasi...

perputaran karyawan yang mengganggu kinerja perusahaan dan cukup memakan banyak biaya dan waktu untuk setiap organisasi. Berkaitan dengan upaya perusahaan untuk meminimalkan tingkat perputaran karyawan, manajemen memiliki tugas yang sangat penting, yakni menciptakan retensi karyawan karena karyawan bersifat aset perusahaan. Perusahaan lebih memilih mempertahankan karyawan daripada merekrut karyawan baru karena dengan memelihara retensi karyawan, perusahaan bisa meminimalkan biaya yang dikeluarkan untuk merekrut karyawan baru.

Kompensasi merupakan keseluruhan balas jasa yang diterima oleh karyawan sebagai balas jasa dari pelaksanaan pekerjaan di organisasi dalam bentuk uang atau lainnya, yang dapat berupa gaji, upah, bonus, insentif, dan tunjangan seperti tunjangan kesehatan, tunjangan hari raya, uang makan, cuti dan lain-lain (Rachmawati, 2011:146).Handaru (2013), menyatakan kompensasi merupakan bentuk penghargaan yang diberikan kepada karyawan sebagai balas jasa atas kontribusi yang mereka berikan kepada organisasinya. Besarnya kompensasi mencerminkan status, pengakuan, dan tingkat pemenuhan kebutuhan yang dinikmati oleh karyawan beserta keluarganya.

Vicky (2012), berpendapat bahwa kompensasi adalah strategi perusahaan untuk memberdayakan tenaga kerja, dan dapat berfungsi sebagai keunggulan kompetitif perusahaan.Biasanya kompensasi sebagai alasan yang utama bagi karyawan untuk bergabung dalam sebuah perusahaan.Kompensasi yang adil lebih mungkin untuk menarik, mengembangkan, memotivasi dan mempertahankan pegawai yang berkualitas dan kompeten (Quartey, 2013). Rivai (2014: 357), 
menyatakan kompensasi merupakan sesuatu yang diterima karyawan sebagai pengganti kontribusi jasa mereka pada perusahaan.Sedarmayanti (2010:239), menyatakan bahwa tujuan dari sistem kompensasi adalah mempertahankan karyawan, mengendalikan biaya, dan memperoleh karyawan yang bermutu yang nantinya sesuai dengan harapan dan keinginan organisasi.

Grace (2013), menyatakan bahwa persepsi dukungan organisasi didefinisikan sebagai kepercayaan karyawan bahwa organisasi menghargai kontribusi dan kesejahteraan mereka. Teori dukungan organisasi beranggapan bahwa untuk organisasi memberikan rewards (penghargaan)atas peningkatan kinerja dan memenuhi kebutuhan sosio-emosional, karyawan terhadap organisasi, mengembangkan kepercayaan bahwa organisasi menghargai kontribusi dan memperhatikan kesejahteraan mereka. Tingginya persepsi dukungan organisasi akan mempengaruhi keterikatan karyawan dalam perusahaan (Mujiasih,2015). Wu Wann (2011), menyatakan bahwa persepsi dukungan organisasi mengacu pada persepsi karyawan atau penilaian tentang berapa banyak organisasi menghargai kontribusi mereka dan peduli tentang mereka.

Karyawan melihat pekerjaan mereka sebagai hubungan pertukaran timbal balik yang mencerminkan relatif ketergantungan dan melampaui kontrak resmi. Karyawan perlu menentukan apakah, dan sejauh mana, organisasi akan memperhatikan dan menghargai usaha mereka, mendukung kebutuhan sosioemosional mereka, dan membantu mereka atas permintaan. Perlakuan yang adil, dukungan pengawasan, dan penghargaan dan kondisi kerja yang menguntungkan menunjukkan hubungan yang kuat dengan dukungan organisasi yang dirasakan. 
I Gde Manik Aditya Budi Suta, Pengaruh Kompensasi...

Dari pernyataan tersebut, persepsi dukungan organisasi adalah seberapa besar dukungan organisasi yang dirasakan karyawan terhadap kontribusi mereka dan kepedulian organisasi terhadap kesejahteraan mereka yang akan berdampak kepada dukungan karyawan terhadap organisasi.

Mathis dan Jackson (2011:128), menyatakan bahwa retensi karyawan juga dipengaruhi oleh faktor pengembangan karir secara siginifikan.Untuk meningkatkan kerja karyawan dalam suatu organisasi diperlukannya pengembangan karir bagi setiap karyawan guna melatih keterampilan dalam bekerja. (Meyer \& Smith, 2000). Kwenin (2013), menyatakan bahwa organisasi yang memberikan pelatihan, fasilitas pendidikan kepada karyawan maka karyawan tersebut lebih setia kepada perusahaan dengan jangka waktu yang lama dan dapat meningkatkan retensi karyawan. Cao et al. (2013), menyatakan bahwa organisasi perlu menjalankan program pelatihan dan pengembangan untuk memperkuat hubungan dan mempertahankan karyawan. Ardana dkk. (2012:117), menyatakan bahwa pengembangan karir adalah peningkatan pribadi yang dilakukan seseorang untuk mencapai suatu rencana karir dan peningkatan oleh departemen personalia untuk mencapai suatu rencana kerja sesuai dengan jalur atau jenjang organisasi.

Penelitian yang dilakukan oleh Hafanti (2015), yang berjudul pengaruh kompensasi, lingkungan kerja dan desain tugas terhadap kepuasan kerja dan dampaknya terhadap retensi karyawan Palang Merah Indonesia (PMI) Provinsi Aceh dengan menggunakan sampel dari keseluruhan karyawan yang berjumlah 115 orang dan menggunakan analisis jalur (path analysis) membuktikan bahwa 
kompensasi berpengaruh positif terhadap retensi karyawan Palang Merah Indonesia Provinsi Aceh.

Swambawa Putra (2016), dengan penelitian yang berjudul pengaruh kompensasi, lingkungan kerja dan perceived organizational support (persepsi dukungan organisasi) terhadap retensi karyawan Gree Villas Hotel Tuban Bali dengan menggunakan 72 orang sebagai sampel dan menggunakan teknik analisis regresi linier berganda dengan hasil yang diperoleh bahwa kompensasiberpengaruh positif terhadap retensi karyawan.

Hasil penelitian yang dilakukan oleh Syafi (2013), yang berjudul analisis pengaruh lingkungan kerja, pemberdayaan dan kompensasi terhadap retensi karyawan pada divisi umum LPP TVRI Jakarta dengan menggunakan sampel 130 orang dan menggunakan analisis regresi berganda menyatakan kompensasi berpengaruh signifikan terhadap retensi karyawan.

Anis (2013), melakukan penelitian yang berjudul employee retention relationship to training and development: A compensation perspective (hubungan retensi karyawan dengan pelatihan dan pengembangan: perspektif kompensasi) dengan menggunakan sampel 330 dari 503 populasi orang dan memakai analisis regresi dimana hasil yang di dapat bahwa kompensasi berpengaruh positif terhadap retensi karyawan. Dari beberapa penelitian tersebut, maka dapat ditetapkan hipotesis penelitian sebagai berikut.

$\mathrm{H}_{1}$ : Kompensasi berpengaruh positif dan signifikan terhadap retensi karyawan.

Sukharski (2002), dengan penelitian yang berjudul perceived supervisor support: contributions to perceived organizational support and employee 
I Gde Manik Aditya Budi Suta, Pengaruh Kompensasi...

retention (dukungan supervisor yang dirasakan: kontribusi untuk dukungan organisasi yang dirasakan dan retensi karyawan) dengan menggunakan 306 orang sebagai sampel dan menggunakan teknik analisis regresi standar dengan hasil yang di dapat bahwa ada pengaruh positif tetapi tidak signifikan antara perceived organizational support (persepsi dukunga organisasi) terhadap retensi karyawan.

Penelitian yang dilakukan oleh Boyd and Smith (2011), yang berjudul perceived organizational support (POS) and retention of rural special education teacher ( persepsi dukungan organisasi dan retensi guru pendidikan khusus pedesaan) dengan menggunakan sampel 50 orang dan memakai analisis regresi dengan hasil yang di peroleh bahwa ada pengaruh positif dari perceived organizational support (persepsi dukungan organisasi) terhadap retensi.

Cahyana(2012), dengan judul penelitian analisis pengaruh perceived organizational support dan organizational trust( persepsi dukungan organisasi dan kepercayaan organisasi)terhadap kepuasan karyawan dan dampaknya terhadap retensi karyawan pada PT. Lestarindo Perkasa dengan menggunakan sampel 45 orang dan menggunakan path analysis (analisis jalur)dari hasil penelitian di dapatkan bahwa perceived organizational support (persepsi dukungan organisasi) berpengaruh positif namun tidak signifikan terhadap retensi karyawan.

Demikian pula dengan Swambawa Putra (2016), dengan penelitian yang berjudul pengaruh kompensasi, lingkungan kerja dan perceived organizational support (persepsi dukungan organisasi) terhadap retensi karyawan Green Villas Hotel Tuban Bali dengan menggunakan 72 orang sebagai sampel dan 
menggunakan teknik analisis regresilinier berganda dengan hasil yang diperoleh bahwa perceived organizational support (persepsi dukungan organisasi) mempengaruhi retensi karyawan secara positif.Dari beberapa penelitian tersebut, maka dapat dikembangkan hipotesis sebagai berikut.

$\mathrm{H}_{2}$ :Persepsi dukungan organisasi berpengaruh positif dan signifikan terhadap retensi karyawan.

Cao et al. (2013), menyatakan bahwa organisasi perlu menjalankan program-program pelatihan dan pengembangan kepada karyawan jika organisasi ingin memperkuat hubungan dan mempertahankan karyawan.

Penelitian yang dilakukan oleh Kwenin (2013), menyatakan bahwa pengembangan karir berpengaruh terhadap retensi karyawan di Vodafone Ghana Limited secara positif.

Peneilitian yang dilakukan Poerbaningtyas (2015), yang berjudul analisis pengaruh pengembangan karir dan kinerja karyawan terhadap retensi karyawan pada PT.NET Mediatama Indonesia dengan menggunakan 80 orang sebagai sampel dengan teknik analisis regresi linier berganda dengan hasil yang diperoleh bahwa pengembangan karir berpengaruh signifikan terhadap retensi karyawan.

Pratiwi (2017), dengan penelitian yang berjudul pengaruh lingkungan kerja dan pengembangan karir terhadap retensi karyawan pada Hotel Santika Nusa Dua Bali dengan menggunakan 84 orang sebagai sambil dengan teknis analisi regresi linear berganda dengan hasil bahwa pengembangan karir berpengaruh positif dan signifikan tehadap retensi karyawan. Dari beberapa penelitian, maka dapat dikembangkan hopitesis sebagai berikut. 
I Gde Manik Aditya Budi Suta, Pengaruh Kompensasi...

$\mathrm{H}_{3}$ : Pengembangan karir berpengaruh positif dan signifikan terhadap retensi karyawan.

\section{METODE PENELITIAN}

Lokasi penelitian ini adalah di PT.BPR Gianyar Partasedana yang berlokasi di Jalan Raya Buruan No. 88 Blahbatuh Gianyar. Lokasi tersebut dipilih sebagi tempat penelitian karena belum banyak yang melakukan penelitian dilokasi tersebut dan memiliki indikasi permasalahan mengenai retensi karyawan yang rendah. Variabel terikat dalam penelitian ini adalah retensi karyawan (Y). Variabel bebas dalam penelitian ini adalah kompensasi $\left(\mathrm{X}_{1}\right)$, persepsi dukungan organisasi $\left(\mathrm{X}_{2}\right)$, dan pengembangan $\operatorname{karir}\left(\mathrm{X}_{3}\right)$.

Populasi pada penelitian ini adalah keseluruhan karyawan tetap yang ada di PT.BPR Gianyar Partasedana, namun tidak termasuk manajer.Jumlah sampel yang digunakan dalam penelitian ini sebanyak 53 responden. Metode penentuan sampel dalam penelitian ini adalah non-probability sampling dengan menggunakan teknik sampling jenuh karena dalam penelitian ini melibatkan semua anggota populasi untuk dijadikan sampel, dengan total sebanyak 53 sampel.

Model analisis yang digunakan untuk menyelesaikan permasalahan penelitian ini adalah regresi linear berganda.Permasalahan yang harus dijawab adalah variabel bebas (Kompensasi, Persepsi Dukungan Organisasi,dan Pengembangan Karir) berpengaruh secara simultan, secara parsial, dan dominan terhadap variabel terikat (Retensi).Model regresi linear berganda dengan menggunakan persamaan sebagai berikut. 


$$
\mathrm{Y}=\alpha+\beta_{1} \mathrm{X}_{1}+\beta_{2} \mathrm{X}_{2}+\beta_{3} \mathrm{X}_{3}+\mathrm{e}
$$

Keterangan:

$$
\begin{array}{ll}
\mathrm{Y} & =\text { Retensi } \\
\alpha & =\text { Konstanta } \\
\beta & =\text { Koefisien regresi } \\
\mathrm{X}_{1} & =\text { Kompensasi } \\
\mathrm{X}_{2} & =\text { Persepsi dukungan organisasi } \\
\mathrm{X}_{3} & =\text { Pengembangan karir } \\
\mathrm{e} & =\text { Kesalahan residual (error) }
\end{array}
$$

\section{HASIL PENELITIAN DAN PEMBAHASAN}

Karakteristik responden yang diteliti dalam penelitian ini meliputi tiga aspek yaitu jenis kelamin, usia, dan pendidikan terakhir.Ringkasan mengenai karakteristik responden dapat dilihat pada Tabel 2, Tabel 3, dan Tabel 4. Tabel 2.

Karakteristik responden dilihat dari jenis kelamin yang ditunjukkan pada

Tabel 2.

Distribusi Responden Menurut Jenis Kelamin pada

PT. BPR Gianyar Partasedana Tahun 2018

\begin{tabular}{cccc}
\hline No & Jenis Kelamin & $\begin{array}{c}\text { Jumlah } \\
\text { Orang }\end{array}$ & Persen (\%) \\
\hline 1 & Laki-laki & 23 & 43 \\
2 & Perempuan & 30 & 57 \\
& Jumlah & 53 & 100 \\
\hline
\end{tabular}

Kriteria jenis kelamin responden dapat digunakan sebagai acuan untuk mengetahui proporsi responden laki-laki dan perempuan. Tabel 2 menunjukkan bahwa sebagian besar karyawan di PT.BPR Gianyar Partasedana berjenis kelamin perempuan yaitu berjumlah 30 responden (57 persen) dibandingkan karyawan laki-laki berjumlah 23 responden (43 persen). Karyawan didominasi oleh jenis kelamin perempuan karena bidang pekerjaan yang sesuai dengan kemampuan 
perempuan dan memiliki penampilan menarik yaitu teller, customer service, accounting, marketing dana, kepala bagian umum dan IT.

Karakteristik responden dilihat dari usia yang ditunjukkan pada Tabel 3.

Tabel 3.

Distribusi Responden Menurut Usia pada PT. BPR Gianyar Partasedana Tahun 2018

\begin{tabular}{llll}
\hline No & Usia & $\begin{array}{l}\text { Jumlah } \\
\text { Orang }\end{array}$ & Persen (\%) \\
\hline 1 & $21-30$ & 20 & 38 \\
2 & $31-40$ & 23 & 43 \\
3 & $41-50$ & 8 & 15 \\
4 & $51-60$ & 2 & 4 \\
Jumlah & & 53 & 100 \\
\hline
\end{tabular}

Sumber: Data diolah, 2013

Kriteria usia responden dapat digunakan sebagai acuan untuk mengetahui usia responden pada penelitian ini. Perusahaan menetapkan usia minimal dalam perekrutan karyawan yaitu usia 21 keatas. Tabel 3 menunjukkan bahwa responden yang berusia 21-30 berjumlah 20 responden (38 persen), usia 31-40 berjumlah 23 responden (43 persen), usia 41-50 berjumlah 8 responden (15 persen), dan usia 51-60 berjumlah 2 reponden (4 persen). Perusahaan didominasi oleh karyawan yang berusia 31-40 karena merupakan usia produktif dalam bekerja.

Karakteristik responden dilihat dari pendidikan terakhir yang ditunjukkan pada Tabel 4.

Kriteria tingkat pendidikan dapat digunakan sebagai acuan untuk mengetahui pendidikan terakhir responden pada penelitian ini. Kebijakan perusahaan dalam penerimaan karyawan baru yaitu pendidikan terakhir minimal SMA. Tabel 4.3 menunjukkan bahwa responden dengan tingkat pendidikan SMA berjumlah 9 responden (17 persen), Diploma berjumlah 10 responden (19 persen), 
S1 berjumlah 28 responden (53 persen), dan S2 berjumlah 6 responden (11 persen). Karyawan didominasi oleh pendidikan terakhir S1 karena pekerjaan yang dilakukan membutuhkan keahlian khusus.

Tabel 4.

Distribusi Responden Menurut Tingkat Pendidikan pada PT. BPR Gianyar Partasedana Tahun 2018

\begin{tabular}{lcll}
\hline No & Pendidikan & Jumlah & \\
& & Orang & Persen (\%) \\
\hline 1 & SMA & 9 & 17 \\
2 & Diploma & 10 & 19 \\
3 & S1 & 28 & 53 \\
4 & S2 & 6 & 11 \\
Jumlah & & 53 & 100 \\
\hline
\end{tabular}

Sumber: Data diolah, 2018

Uji regresi linear berganda pada penelitian ini digunakan untuk mengetahui besarnya pengaruh Kompensasi $\left(\mathrm{X}_{1}\right)$, Persepsi dukungan organisasi $\left(\mathrm{X}_{2}\right)$, Pengembangan karir $\left(\mathrm{X}_{3}\right)$ dan Retensi karyawan (Y). Metode ini diuji menggunakan sistem komputer berupa spss.21. Pengaruh variabel independen terhadap variabel dependen diuji dengan tingkat kepercayaan 95\% atau $\alpha=5 \%$. Berdasarkan hasil olah data, maka hasil uji regresi linear berganda pada penelitian ini yaitu:

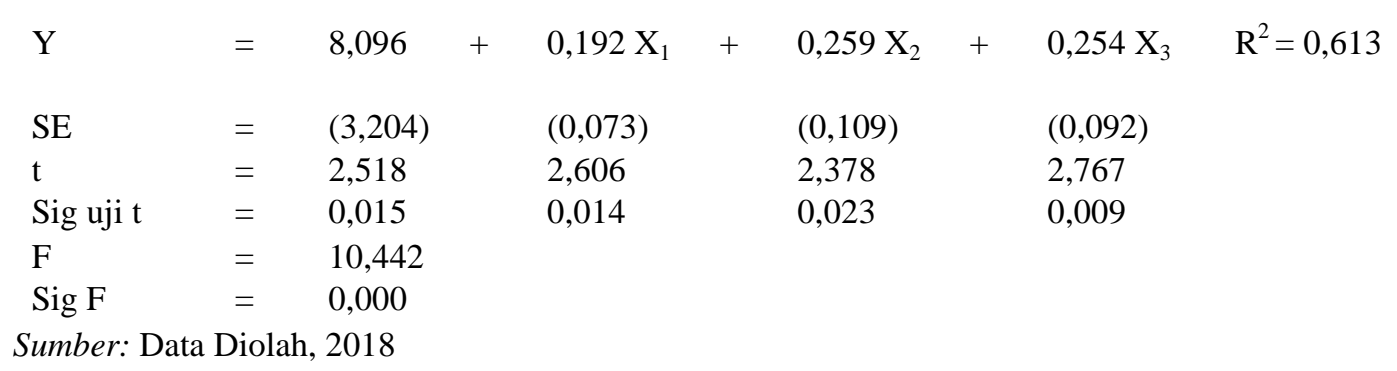

Hasil perhitungan analisis regresi linear berganda, maka didapatkan hasil persamaan regresi sebagai berikut.

$$
Y=0,192 X_{1}+0,259 X_{2}+0,254 X_{3}
$$


Dimana :

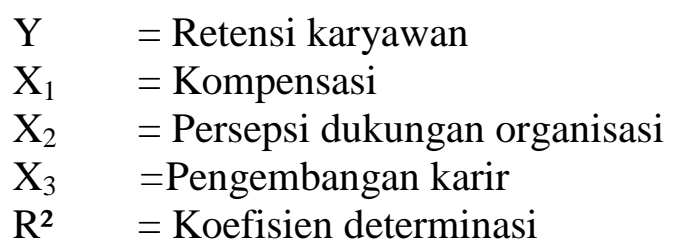

Nilai koefisien $b_{1}=0,192$ berarti kompensasi $\left(X_{1}\right)$ berpengaruh positif dan signifikan terhadap retensi karyawan (Y), dengan asumsi variabel bebas dianggap konstan.Nilai koefisien $b_{2}=0,259$ berarti persepsi dukungan organisasi $\left(X_{2}\right)$ berpengaruh positif dan signifikan terhadap retensi karyawan (Y), dengan asumsi variabel bebas dianggap konstan.Nilai koefisien $b_{3}=0,254$ berarti pengembangan karir $\left(\mathrm{X}_{3}\right)$ berpengaruh positif dan signifikan terhadap retensi karyawan (Y), dengan asumsi variabel bebas dianggap konstan.

Nilai $\mathrm{R}^{2}=$ Nilai $\mathrm{R}^{2}$ adalah sebesar 0,613 yang artinya sebesar 61,3 persen retensi karyawan dipengaruhi oleh kompensasi, persepsi dukungan organisasi dan pengembangan karir. Sebesar 39,7 persen dipengaruhi oleh faktor lain.

Hasil uji menyatakan bahwa nilai signifikansi $F$ adalah sebesar 0,000 yang lebih kecil dari $0,05(\mathrm{~F}<\alpha)$ yang berarti variabel bebasyaitu kompensasi $\left(\mathrm{X}_{1}\right)$, persepsi dukungan organisasi $\left(\mathrm{X}_{2}\right)$, dan pengembangan karir $\left(\mathrm{X}_{3}\right)$ berpengaruh signifikan secara serempak terhadap variabel terikat yaitu retensi karyawan (Y), sehingga penelitian ini dapat dikatakan memenuhi uji kelayakan model atau model penelitian dinyatakan layak digunakan sebagai model regresi.

Tabel 5.

Hasil Uji Koefisien Determinasi $\left(\mathbf{R}^{2}\right)$

\begin{tabular}{ccccc}
\hline Model & R & Rquare & Adjusted R Square & $\begin{array}{l}\text { Std. Error of the } \\
\text { Estimate }\end{array}$ \\
\hline 1 & 0,783 & 0,613 & 0,554 & 1.121 \\
\hline Sumber:Data diolah 2018 & & &
\end{tabular}

Sumber:Data diolah,2018 
Besarnya nilai kofisien determinasi $\mathrm{R}$ square adalah 0,613 yang artinya sebesar 61,3 persen variasi retensi karyawan dipengaruhi oleh kompensasi, persepsi dukungan organisasi, dan pengembangan karir, sedangkan sisanya sebesar 39,7 persen dipengaruhi oleh faktor-faktor lain yang tidak dimasukkan ke dalam penelitian.

Interprestasi hasil analisis dilakukan dengan memperhatikan hasil validasi model hipotesis yang disajikan pada Tabel 3 .

Tabel 6.

Hasil Uji t

\begin{tabular}{cllllll}
\hline Model & \multicolumn{3}{c}{ Unstandardized Coefficients } & $\begin{array}{l}\text { Standardized } \\
\text { Coefficients } \\
\text { Beta }\end{array}$ & t & Sig. \\
& & B & Std. Error & Beta & 2,518 & 0,015 \\
& Constant & 8,069 & 3,204 & & 2,606 & 0,014 \\
1 & X1 & 0,192 & 0,073 & 0,342 & 2,378 & 0,023 \\
& X2 & 0,259 & 0,109 & 0,276 & 2,767 & 0,009 \\
\hline
\end{tabular}

Sumber:Data diolah, 2018

Hipotesis $\left(\mathrm{H}_{1}\right)$ menyatakan kompensasi berpengaruh terhadap retensi karyawan. Setelah dilakukan penelitian, hasil penelitian bahwa nilai koefisien beta positif sebesar 0,192 dengan nilai signifikansi sebesar 0,014 yang lebih kecil dari 0,05 mengindikasikan bahwa kompensasi berpengaruh positif dan signifikan terhadap retensi karyawan.Hal ini sejalan dengan penelitian yang dilakukan (Vicky,2012) mendapatkan hasil bahwa kompensasi berpengaruh positif terhadap retensi karyawan dan karyawan akan bertahan diperusahaan.

Hafanti (2015) dalam penelitiannya membuktikan bahwa kompensasi memiliki pengaruh positif terhadap retensi karyawan. Handaru (2013) menyatakan kompensasi merupakan bentuk penghargaan yang diberikan kepada karyawan sebagai balas jasa atas kontribusi yang diberikan kepada organisasi agar karyawan 
I Gde Manik Aditya Budi Suta, Pengaruh Kompensasi...

merasa puas dan bertahan diperusahaan. Sedarmayanti (2010:239) menyatakan bahwa tujuan dari kompensasi adalah mempertahankan karyawan, mengendalikan biaya dan memperoleh karyawan yang bermutu yang nantinya sesuai dengan harapan dan keinginan organisasi.

Hipotesis $\left(\mathrm{H}_{2}\right)$ menyatakan persepsi dukungan organisasi berpengaruh terhadap retensi karyawan. Setelah dilakukan penelitian, hasil penelitian bahwa nilai koefisien beta positif sebesar 0,259 dengan nilai signifikansi sebesar 0,023 yang lebih kecil dari 0,05 mengindikasikan bahwa persepsi dukungan organisasi berpengaruh positif dan signifikan terhadap retensi karyawan. Swambawa Putra (2016) dalam penelitiannya memperoleh hasil bahwa persepsi dukungan organisasi berpengaruh positif terhadap retensi karyawan. Cahyana (2012) menyatakan bahwa apabila perusahaan ingin mempertahankan dan meningkatkan retensi karyawan, maka perusahaan harus meningkatkan dukungan organisasi kepada karyawan agar karyawan merasa diperhatikan. Tingginya tingkat persepsi dukungan organisasi didalam perusahaan akan mengarah kepada kepuasan kerja, menurunnya tingkat turn over dan meningkatkan retensi karyawan (Robbins dan Coulter,2014:143).

Hipotesis $\left(\mathrm{H}_{3}\right)$ menyatakan pengembangan karir berpengaruh terhadap retensi karyawan. Setelah dilakukan penelitian, hasil penelitian bahwa nilai koefisien beta positif sebesar 0,254 dengan nilai signifikansi sebesar 0,009 yang lebih kecil dari 0,05 mengindikasikan bahwa pengembangan karir berpengaruh positif terhadap retensi karyawan. Cao et al. (2013) menyatakan bahwa pengembangan karir karyawan sangat penting untuk mempertahankan karyawan. 
Kwenin (2013) dalam penelitiannya menemukan bahwa retensi karyawan dipengaruhi oleh pengembangan karir secara signifikan. Mathis dan Jackson (2011:128) menyatakan bahwa retensi karyawan dipengaruhi oleh faktor pengembangan karir secara signifikan. Kesempatan untuk pelatihan dan pengembangan keterampilan merupakan bagian dari pengembangan karir yang akan meningkatkan retensi karyawan (Meyer \& Smith, 2000).

Implikasi dari hasil penelitian ini dibagi menjadi dua bagian, yaitu implikasi teoritis dan implikasi praktis bahwa bagi peneliti selanjutnya yang mengangkat topik sejenis diharapkan dapat menambah indikator yang belum dimasukkan dalam penelitian ini, menggunakan perusahaan perbankan yang lain, serta mengukur variabel lain yang mempengaruhi retensi karyawan.

Berdasarkan data responden karyawan dapat dilihat bahwa semua variabel yaitu kompensasi, persepsi dukungan organisasi dan pengembangan karir memiliki pengaruh positif dan signifikan terhadap retensi karyawan. Dengan demikian pihak manajemen BPR diharapkan dapat mengelola dan mempertahankan karyawan yang berkualitas baik untuk kesehatan jangka panjang perusahaan.

Penelitian ini memiliki keterbatasan generalisasi, keterbatasan waktu dan keterbatasan tenaga, dimana penelitian ini hanya dilakukan di satu perusahaan saja yaitu PT. BPR Gianyar Partasedana.

\section{SIMPULAN DAN SARAN}

Kesimpulan yang dapat ditarik dalam penelitian ini bahwa kompensasi memiliki pengaruh positif dan signifikan terhadap retensi karyawan PT. BPR 
I Gde Manik Aditya Budi Suta, Pengaruh Kompensasi...

Gianyar Partasedana. Hal ini menunjukkan bahwa semakin besar kompensasi yang diberikan perusahaan kepada karyawan maka akan meningkatkan retensi karyawan di PT. BPR Gianyar Partasedana.

Persepsi dukungan organisasi memiliki pengaruh positif dan signifikan terhadap retensi karyawan PT. BPR Gianyar Partasedana. Hal ini menunjukkan bahwa semakin besar dukungan organisasi yang diberikan perusahaan kepada karyawan maka akan meningkatkan retensi karyawan di PT. BPR Gianyar Partasedana.

Pengembangan karir memiliki pengaruh positif dan signifikan terhadap retensi karyawan PT. BPR Gianyar Partasedana. Hal ini menunjukkan bahwa ketika pengembangan karir diterapkan dengan sangat baik didalam organisasi maka akan meningkatkan retensi karyawan di PT. BPR Gianyar Partasedana.

Saran yang dapat diberikan kepada pihak perusahaan yaitu PT. BPR Gianyar Partasedana harus mampu memberikan tunjangan dan insentif yang merata bagi seluruh karyawan. Perusahaan juga harus mampu memberikan fasilitas kerja yang layak bagi setiap karyawan. Sistem kompensasi yang baik dipercaya dapat meningkatkan retensi karyawan untuk jangka waktu yang lama.

Pihak PT. BPR Gianyar Partasedana hendaknya mampu memberikan dukungan dan perhatian demi kenyamanan karyawan dalam melakukan pekerjaan. Karyawan yang diperhatikan akan merasa nyaman dalam melakukan pekerjaan dan dipercaya dapat meningkatkan retensi karyawan pada PT. BPR Gianyar Partasedana. 
Pihak PT. BPR Gianyar Partasedana diharapkan lebih memperhatikan pengembangan karir karyawan dengan menyiapkan peluang untuk promosi dan perlunya mentor untuk bimbingan formal, sehingga karyawan dapat menguasai pekerjaan yang dimiliki sesuai dengan tanggung jawab yang didapat. Karyawan agar dapat bertahan lama, perusahaan juga menyediakan peluang karir bagi setiap karyawan.

\section{REFERENSI}

Anis. (2013). Employee Retention Relationship to Training and Development: A Compensation Perspective. African Journal of Business Management, 5(7), pp: 2679-2685.

Ardana, Komang, Ni Wayan Mujiati dan I Wayan Mudiartha Utama. (2012) .Manajemen Sumber Daya Manusia. Edisi I. Yogyakarta. Graha Ilmu.

Ariana, I Wayan Tresna dan Riana, I Gede. (2013). Pengaruh Kepemimpinan, Kompensasi dan Disiplin Kerja Terhadap Kinerja Karyawan Pada Hotel Cendana Resort \& Spa Ubud, Gianyar. E-Jurnal Manajemen Universitas Udayana. 2 (1), pp: 121-136.

Benlioglu, Benek. (2014). The Examination of The Effect of Perceived Organizational Support of University Teaching Staff on Organisational Commitment. Mevlana International Journal of Education (MIJE), 4(2), pp: $37-51$.

Boyd Michelle dan Tina Smith. (2011). Perceived Organizational Support (POS) and Retention of Rural Special Education Teacher.Journal of CrossDisciplinary Perspectives in Education. Vol. 4. No 1. pp: 18-23

Cahyana, Bodhi. (2012). Analisis Pengaruh Perceived Organizational Support dan Organizational Trust Terhadap Kepuasan Karyawan dan Dampaknya Terhadap Retensi Karyawan pada PT. Lestarindo Perkasa. Binus University.

Cao, Zhoutgo., Jinxi Chen \& Yixiao Song. (2013). Does Total Reward Reduce the Core Employees Turnover Intention. International Journal of Business and Management, 8(20), pp: 62-75.

Das, Bidisha Lahkar dan Mukulesh Baruah. (2013). Employee Retention: A Review Of Literature. IOSF Journal of Business and Management (IOSRJBM), 14 (2), pp: 08-16 
Dessler, G. (2013). Manajemen Personalia. Jakarta:Erlangga.

Farasat, Ebrahim. (2013). Perceived Organizational Support and Deviant Behavior. Journal of Basic and Applied Scientific Research, 3(5), pp: 517528.

Grace. (2013). Hubungan Antara Perceived Organizational Support dengan Work Engagement Pada Guru SMA Swasta di Surabaya. Jurnal Psikologi Industri dan Organisasi, 2(2), pp: 90-99.

Gunawan, Yurika. (2011). Analisis Manajemen Karir, Lingkungan Kerja, dan Kepuasan Kerja Terhadap Retensi Karyawan serta Dampaknya Terhadap Kinerja Perusahaan pada PT Origa Mulia FRP. Skripsi Binus University Jakarta, Indonesia.

Hafanti, Oktina. (2015). Pengaruh Kompensasi, Lingkungan Kerja, dan Desain Tugas Terhadap Kepuasan Kerja dan Dampaknya Terhadap Retensi Karyawan PMI Aceh. Jurnal Manajemen, 4(1), pp: 164-173.

Handaru. (2013). Pengaruh Lingkungan Kerja, Kompensasi dan Komitmen Organisasional terhadap Kepuasan Kerja Karyawan di RS X. Jurnal Riset Manajemen Sains Indonesia. 4(1). pp: 117-135.

Haryani, Putu Yeni. (2013). Korelasi Antara Pengembangan Karir Dengan Motivasi Kerja Dan Keinginan Untuk Pensiun Dini. Jurnal Buletin Study Ekonomi. 2 (6), pp: 116-120.

Hasibuan, Malayu S. P.(2014). Manajemen Sumber Daya Manusia. Edisi revisi. PT. Bumi Aksara: Jakarta.

Karthi, (2012). A Study on Employee Retention in Leading Multional Automobile Sector in India. 2(9), pp:1474-1482.

Kwenin, Daisy. (2013). Relationship Between Work Environment, Career Development Opportunities and Employee Retention in Vodafone Ghana Limited. Journal of Human Resource Management. 1(4), pp: 1-9.

Lubis, Rahman. (2015). Pengaruh Kompensasi, Lingkungan Kerja dan Desain Tugas Terhadap Kepuasan Kerja dan Dampaknya Terhadap Retensi Karyawan PMI. Jurnal Manajemen, 4(1), pp: 164-173.

Mathis, Robert L and Jackson, John H. (2011).Human Resource Management. Tenth Edition. Jakarta: Salemba Empat.

Meyer, J.P., C.A. Smith. (2000). HRM Practices and Organizational Commitment: Test of A Mediation Model. Canadian Journal of Administrative Sciences. 17 (4). pp: 319-331. 
Mujiasih, E. (2015). Hubungan antara perceived organizational support dengan employee engagement.Jurnal Psikologi Undip, 14(1): 40-51.

Mustika, Silvia Indra., Kusdi Rahardjo. (2017). Pengaruh Perceived Organizational Support Terhadap Employe Engagement Dan Organizational Citizenship Behaviour Pada Staf Medis Rumah Sakit Lavalette Malang. Jurnal Administrasi Bisnis (JAB) Vol. 47. No.1

Oladopo, Victor. (2014). The Impact of Talent Management on Retention. Journal of Business Studies Quarterly. 5(3). pp: 20-36

Paille and Boudeau. (2010). Support, Trust, Satisfaction, Intent to Leave and Citizenship at Organizational Level: A Social Exchange Approach. International journal of Organizational Analysis. 18(1). pp: 41-58

Panggabean, Mutiara Sibarani. (2014). Pengaruh Kompensasi Terhadap Retensi Karyawan Melalui Kepuasan Kerja dan Komitmen Afektif Pada Beberapa Rumah Sakit di DKI Jakarta. Jurnal Manajemen Pascasarjana Universitas Syiah Kuala. Vol. 7. No.1.

Poerbaningtyas, Lestari Shalihah. (2015). Analisis Pengaruh Pengembangan Karir dan Kinerja Karyawan Terhadap Retensi Karyawan pada Divisi Produksi PT. NET Mediatama Indonesia. Binus University.Jakarta Indonesia.

Pratiwi, Luh Putu Yunia Anggy. (2017). Pengaruh Lingkungan Kerja dan Pengembangan Karir Terhadap Retensi Karyawan pada Hotel Santika Nusa Dua Bali. E-Jurnal Manajemen Unud, 6 (3), h: 1478-1506.

Quarty. (2013). Is There A Link Between Compensation Packages and Job Performance In The Ghana Police Service.Journal of Business Management, 7 (44), pp: 4398-4406.

Rachmawati, Kusdyah Ike. (2011). Manajemen Sumber Daya Manusia. Yogyakarta:ANDI

Ragupathi. (2013). The Employee Rtenetion Practices of MNC's in Hyderabad. Research Journal of Management Sciences. 2(4), pp: 21-24

Rivai, Veithzal. (2014). Manajemen Sumber Daya Manusia untuk Perusahaan, Dari Teori ke Praktek.Jakarta: PT Raja Grafindo Persada.

Rhoades dan Eisenberger, R. (2002). Perceived Organizational Support: A Review of The Literature. Journal of Applied Psychology, pp: 698-714.

Robbins dan Mary Coulter. (2014). Manajemen Jilid 1 Edisi Kesepuluh. Jakarta: Erlangga. 
Sari, Yanti Komala. (2014). Pengaruh Kepemimpinan, Motivasi, dan Disiplin Kerja Terhadap Kinerja Karyawan Pada PT. Patra Komala Di Dumai. Jurnal Tepak Manajemen Bisnis, 6 (2).

Sedarmayanti.(2010). Manajemen Sumber Daya Manusia Reformasi Birokrasi dan Manajemen Pegawai Negeri Sipil. Bandung: PT Refka Aditama.

Swambawa Putra, Ida Bagus Gede. (2016). Pengaruh Kompensasi, Lingkungan Kerja, dan Perceived Organizational Support (POS) Terhadap Retensi Karyawan Green Villas Hotel Tuban Bali. E-Jurnal Manajemen Udayana, 5 (2), pp: 810-837.

Syafi, Giska Pravitasari. (2013). Analsis Pengaruh Lingkungan Kerja, Pemberdayaan dan Kompensasi Terhadap Retensi Karyawan pada Divisi Umum LPP TVRI Jakarta. Jakarta: Program Pascasarjana Universitas Bina Nusantara, 6 (2).

Vicky. (2012). Analisis Pengaruh Kompensasi, Manajemen Konflik pada Retensi Karyawan dan Dampaknya Terhadap Kinerja Karyawan di perusahaan iaga Jaya. Universitas Bina Nusantara.

Wahyuni, Dwi., Hamidah Nayati Utami., dan Ika Ruhana. (2014). Pengaruh Pengembangan Karier Terhadap Prestasi Kerja Karyawan Studi pada Karyawan Tetap PT. Astra International, Tbk Daihatsu Malang. Jurnal Administrasi Bisnis (JAB). 8 (1), h: 1-10.

Wu Wann. (2011). The Impact of Perceived Organizational Support, Job Satisfaction, and Organizational Commitment on Job Performance in Hotel Industry. The $11^{\text {th }}$ International DSI and the $16^{\text {th }}$ APDSI Joiny Meeting. pp:12-19 